\title{
FINANCIAL DISTRESS AND OWNERSHIP STRUCTURE: THE CASE OF SERBIA
}

\author{
Dragana RADJEN - Nemanja STANISIC \\ (Received: 23 March 2015; revision received: 19 September 2015; \\ accepted: 15 October 2016)
}

The main objective of our research is to examine the effects of financial distress on ownership structure and to elaborate on the factors that influence change of ownership in companies that have adopted a reorganisation plan in the Republic of Serbia. Of the 63 sample companies reorganised in bankruptcy proceedings between 2009 and 2015, the ownership structure remained unchanged in 49 companies, while in 35 , the existing owners or their family members remained in charge of key management positions. Using binary logistic regression, we observed that two factors influenced the change in ownership structure: the length of time it takes to resolve the insolvency process and whether the owners were involved in the running of the distressed company before it filed for bankruptcy. The obtained results indicate that corporate governance mechanisms in distressed Serbian companies are not efficient.

Keywords: bankruptcy, reorganisation, financial distress, ownership structure

JEL classification indices: G32, G33, G34

Dragana Radjen, corresponding author. $\mathrm{PhD}$ graduate student of Faculty of Business, Singidunum University, Belgrade. E-mail: dragana.radjen1@gmail.com

Nemanja Stanisic, Professor at Faculty of Business, Singidunum University, Belgrade.

E-mail: nstanisic@singidunum.ac.rs 


\section{INTRODUCTION AND THE INSTITUTIONAL ENVIRONMENT}

This is the first study to examine the effects of financial distress on the ownership structure of distressed companies in the Republic of Serbia (RS). Compared to developed countries (primarily the US and Germany), the RS has distinct corporate governance features and bankruptcy rules that will be explained below.

After privatisation, which commenced in 1991, the majority of Serbian companies have a high level of ownership concentration. The control of management is typically tight, and decision-making authority tends to be concentrated in the hands of a few people. The largest owners are involved both in strategic and day-to-day decisions. Moreover, controlling shareholders appoint managers from among their relatives. In transition economies with a poor legal protection of minority shareholders, ineffective enforcement of contracts, undeveloped capital markets, and institutional shortfalls such as the RS, ownership concentration ensures effective control and the highest rate of return on invested capital (Cerovic et al. 2014). At the same time, the major owners can gain substantial power, which strengthens their position and enables them to expropriate minority shareholders.

Concerning bankruptcy proceedings, the Serbian government adopted a modern bankruptcy law that is very similar to the US and German bankruptcy codes (for details, see Appendix 1). Serbian bankruptcy law envisages that a reorganisation plan can be filed in the Commercial Court together with an insolvency petition (which is called a pre-pack reorganisation plan), or in a regular insolvency proceeding within 90 days after opening the bankruptcy (which is called a reorganisation plan). Only a debtor (i.e. a company's management) has the capacity to file a pre-pack reorganisation plan. In regular bankruptcy proceedings, the debtor, insolvency administrators, creditors, and debtor's owners can file the reorganisation plan. Before a reorganisation plan is filed with the court, the company must meet the insolvency criteria. However, a company's management and its owners are not obliged to declare the bankruptcy of the company once the insolvency criterion is met. In almost all reorganisation cases, the court appoints insolvency administrators who verify the legality of the reorganisation plan and the bankruptcy proceedings, give consent to the company's cash spending, asset disposals, and other measures requested by the court. Voting for a reorganisation plan is within the classes of the creditors' claims, and the number of an individual creditor's votes depends on the value of the claims. Pursuant to the Amendments of the Bankruptcy Law in August 2014, claims of the company's owners and other affiliated persons who are not engaged in the business of lending money as their main activity are classified in a special class, and they do not 
vote for the reorganisation plan. The existing bankruptcy law does not envisage equity class. Also, the interests of the existing owners are not represented through official committees.

Due to an undeveloped capital market, banks are the main liquidity providers to the corporate sector. During the first stage of the crises, the banks usually pursued a soft-loan strategy. The rolling over of bad debts was common. However, the majority of private arrangements with debtors failed, resulting in an increased number of bankruptcy filings recorded in 2011. During the bankruptcy proceedings, the banks retained a passive role, and by supporting the reorganisation plans proposed by the companies' management, they tried to cover up losses and avoided writing off bad debts. Over the last two years, the situation has improved slightly, and the banks have started to assume a more prominent role in the bankruptcy proceedings and the reorganisation process of distressed companies.

The role of the state in bankruptcy proceedings has until now remained passive. In order to avoid the contraction of the entire economy and the social costs that would arise from massive lay-offs, the state predominantly supports the reorganisation of distressed companies. A similar behaviour was also observed in other former socialist economies (Schaffer 1998).

The remainder of the paper is organised as follows. Sections 2 and 3 present the theoretical framework and the hypotheses that we have developed for the purpose of investigating the influence of financial distress on companies' ownership structure. In Section 4, we describe the sample and the data sources, the descriptive statistics, the dependent and explanatory variables used, and, finally, our models. Section 5 includes a discussion of our empirical evidence and the limitations of the research. The final section provides concluding remarks. Appendix 1 shows the differences among the US, German and Serbian bankruptcy rules, while Appendix 2 summarises the research variables.

\section{LITERATURE REVIEW}

Most of the research on the effects of financial distress on corporate control to date is based on the experience of developed economies (primarily the US and Germany), and there are virtually no such or similar studies for transition economies (except for Asia). Analysing 61 US distressed companies, Gilson (1990) determined that bank lenders frequently become major shareholders in companies that adopt a reorganisation plan under Chapter 11: on average, they receive $79 \%$ of the company's shares and a median of $88 \%$. Using a sample of 43 publicly held US companies filing for bankruptcy, LoPucki - Whitford (1993) confirmed a 
significant change in their ownership. The average percentage of shares allocated to old equity holders upon adopting a reorganisation plan was $22 \%$, compared to $62 \%$ for solvent companies. Gilson et al. (2000) found that equity investments in the reorganised companies can be used for the transfer of effective control over the company. New investors owned a median $54 \%$ of equity shares after equity investments in 12 of 63 distressed companies. On examining 184 US companies that declared bankruptcy, Jory - Madura (2010) noted that 33\% of the previous owners did not retain their equity interest in the reorganised companies and that the majority of shares were distributed to creditors $(68 \%$ of them received equity in the reorganised companies). Köke (2001) analysed a sample of 946 German companies and reached the conclusion that changes in ultimate ownership are more frequent for companies with high leverage, while less likely for large companies and those with high ownership concentration. Taking a sample of over 1500 large- and medium-sized German corporations, Heiss - Köke (2004) found that poor performance, weak corporate governance, high leverage, and the small size of the company influenced ownership change in a bank-based economy. The impact of ownership concentration on ownership change is negative for companies that operate under the control of one large shareholder, while companies with a more dispersed ownership structure demonstrate a negative effect in cases involving higher levels of concentration and a positive effect for lower levels. They also concluded that companies with high insider ownership and a complex ownership structure were less likely to experience changes in ownership structure. In their analysis of 267 German companies that suffered from repeated interest coverage shortfalls, Jostarndt - Sautner (2006) observed a significant decrease in ownership concentration as a result of the withdrawal of private investors from the ownership scheme, while the ownership belonging to banks and outside investors nearly doubled. Median ownership concentration, measured by a Herfindahl index, declined from $26 \%$ in the year preceding the distress time to $16 \%$ four years after the distress time.

Given the great involvement of owners in the management of Serbian companies, one of the important findings of previous studies involves the influence of bankruptcy on management turnover. Previous studies conducted for the US and German market point out a negative association between corporate performance and top management turnover. In these markets, top management turnover rates range from 13\% to 91\% (Gilson 1989; LoPucki - Whitford 1993; Betker 1995; Franks - Mayer 2000; Jostarndt - Sautner 2006). 


\section{HYPOTHESES}

The arguments in the above literature review lead us to three main hypotheses describing the influence of financial distress on ownership structure.

Hypothesis 1: A change in ownership structure is less likely for large companies and companies with a complex ownership structure.

Hypothesis 2: A change in ownership structure is less likely for companies with highly concentrated ownership operating under the control of one or a small number of large shareholder(s). At the same time, a change in the ownership structure is more likely for companies in which the owners were involved in the company's management before filing for bankruptcy.

Hypothesis 3: Existing ownership structures are more likely to be changed in companies with poor financial performance and a high level of leverage.

In order to avoid time-consuming alternatives, creditors could support reorganisation plans submitted by the company's management that envisage an unchanged ownership structure for the distressed company upon adopting the reorganisation plan. In this respect, we shall propose an additional hypothesis.

Hypothesis 4: The existing ownership structures are more likely to be changed in the companies that spend a longer time in bankruptcy.

\section{METHODOLOGY AND DESCRIPTIVE STATISTICS}

\subsection{Sample and data sources}

We began our research with the analysis of 69 large and medium-sized privately owned non-financial companies organised as joint-stock or limited liability form. A company is considered to be privately owned when the state owns less than $50 \%$ of the company's shares in the year of filing bankruptcy; otherwise, it is considered to be state owned. The $50 \%$ ownership gives the company's owner sufficient control over its decision-making processes. All of the observed companies had completed bankruptcy through the adoption of a reorganisation plan in accordance with the Bankruptcy Law between January 1, 2009, and June 30, 2015. Our investigation started in 2009 due to the fact that reorganisation plans for the majority of the reorganised companies were not publicly available prior 
to that year. We excluded state-owned companies from our sample because the selection of managers in these companies is highly politicised. Furthermore, we did not analyse financial institutions subject to special bankruptcy regulations.

The official information concerning 69 companies that adopted a reorganisation plan is not publicly available; thus, we obtained the requested information from the Bankruptcy Supervision Agency, as well as from 8 of the 16 commercial courts. The information regarding the reorganisation plans and other relevant data for this research were obtained from the Serbian Business Registers Agency, the Portal of the Serbian Commercial Courts, the insolvency administrators, the companies' official websites, and the Boniteti.rs and Poslovna.rs websites.

In classifying a company as financially distressed, we used the definition of Asquith et al. (1994), who argued that a company is classified as financially distressed if its earnings before interest, taxes, depreciation, and amortisation (EBITDA) are less than the reported interest expense over a span of any two consecutive years, or if EBITDA is less than $80 \%$ of its interest expense in any year. We excluded four companies from the sample, as they were not deemed to be in financial distress. We were not able to retrace the control chain for two companies, which is why they are excluded from the final sample. Our final sample is comprised of 63 medium- and large-sized private companies, organised as joint stock (24 companies: $38 \%$ ) or limited liability (39 companies: 62\%) companies. The average assets of the analysed companies were EUR 23.8 million and sales EUR 14.8 million.

\subsection{Descriptive statistics}

As can be seen in Table 1, the majority of companies in the final sample belonged to the manufacturing industry $(52.4 \%)$, with a significant number belonging to wholesale trade $(17.5 \%)$ and construction $(12.7 \%)$.

The figures presented in Table 2 indicate the increased number of bankruptcy filings starting in 2011 (2011 and 2012: 19\%, 2013: 29\%, 2014: 21\%), with bankruptcy ending as a result of the adoption of a reorganisation plan in $2013(27 \%)$ and $2014(33 \%)$.

With regard to ownership structure, most of the companies in the final sample were owned by individuals and other corporations, while only a small fraction by banks or the state (average share less than 5\%). In companies with a changed ownership structure, the ownership share of individuals decreased by $28 \%$ as a result of debt-equity swaps. As demonstrated in Table 3, the ownership concentration was at a high level in both of the periods observed, with the average equity holdings of the largest owner standing at approximately $70 \%$. The equity holdings of 
Table 1. Sample distribution at the one-digit SIC code level

\begin{tabular}{l|c|c}
\hline Sample & Number & $\%$ \\
\hline Manufacturing & 33 & 52.38 \\
\hline Wholesale trade & 11 & 17.46 \\
\hline Construction & 8 & 12.70 \\
\hline Agriculture, Forestry and Fishing & 4 & 6.35 \\
\hline Real Estate & 3 & 4.76 \\
\hline Transportation, Communications, Electric, Gas, Sanitary Services & 2 & 3.17 \\
\hline Mining & 1 & 1.59 \\
\hline Retail trade & 1 & 1.59 \\
\hline Total & 63 & 100.00 \\
\hline
\end{tabular}

Table 2. Sample distribution per bankruptcy filing year and the year in which bankruptcy ended

\begin{tabular}{l|c|c|c|c}
\hline \multirow{2}{*}{ Year } & \multicolumn{2}{|c|}{ Bankruptcy filing year } & \multicolumn{2}{c}{ Year in which bankruptcy ended } \\
\cline { 2 - 5 } & Frequency & $\%$ & Frequency & $\%$ \\
\hline 2009 & 1 & 1.6 & 0 & 0.0 \\
\hline 2010 & 7 & 11.1 & 3 & 4.8 \\
\hline 2011 & 12 & 19.1 & 8 & 12.7 \\
\hline 2012 & 12 & 19.1 & 6 & 27.0 \\
\hline 2013 & 18 & 28.6 & 17 & 33.3 \\
\hline 2014 & 13 & 20.6 & 21 & 12.7 \\
\hline 2015 & 0 & 0.0 & 8 & 100.0 \\
\hline Total & 63 & 100.0 & 63 & \\
\hline
\end{tabular}

the second largest owner also stayed at a stable level (11-13\%). More than 70\% of the companies with a changed and unchanged ownership structure had their ultimate owner in a filing year, while after the adoption of the reorganisation plan, $57 \%$ of the companies with a changed ownership structure had their ultimate owner. In terms of the complexity of the ownership structure, a pyramid ownership structure was frequently found for all of the observed companies (i.e. more than half of them employed a pyramidal structure), while cross-ownership was rare (only four companies in the sample employed cross-ownership).

During the observed period, the ownership structure changed for 14 companies; in four of them, the previous owners retained a decreased ownership share with an average decrease of equity holdings by $75 \%$, while for 10 companies, the ownership structure changed completely (i.e. the previous owners did not retain equity holdings in the reorganised companies). In one company, the reorganisation plan envisaged a debt-to-equity conversion immediately after the adoption of the plan. For the purpose of this research, we assumed that the debt-to-equity conversion was finalised by the end of June 2015, despite the fact that it was 
Table 3. Composition of the ownership structures between the groups and the bankruptcy periods

\begin{tabular}{|c|c|c|c|c|c|c|c|c|}
\hline \multirow[b]{3}{*}{ Equity holdings } & \multicolumn{8}{|c|}{ Bankruptcy filing year } \\
\hline & \multicolumn{4}{|c|}{ Change in ownership } & \multicolumn{4}{|c|}{ No change in ownership } \\
\hline & Min. & Max. & Mean & $\begin{array}{c}\text { Std. } \\
\text { deviation }\end{array}$ & Min. & Max. & Mean & $\begin{array}{c}\text { Std. } \\
\text { deviation }\end{array}$ \\
\hline Individuals & 0.00 & 1.00 & 0.42 & 0.45 & 0.00 & 1.00 & 0.54 & 0.44 \\
\hline Corporations & 0.00 & 1.00 & 0.57 & 0.44 & 0.00 & 1.00 & 0.44 & 0.44 \\
\hline State & 0.00 & 0.12 & 0.01 & 0.03 & 0.00 & 0.33 & 0.01 & 0.05 \\
\hline Banks & 0.00 & 0.23 & 0.01 & 0.06 & 0.00 & 0.07 & 0.00 & 0.01 \\
\hline $1^{\text {st }}$ largest owner & 0.23 & 1.00 & 0.68 & 0.24 & 0.14 & 1.00 & 0.753 & 0.27 \\
\hline $2^{\text {nd }}$ largest owner & 0.00 & 0.44 & 0.14 & 0.13 & 0.00 & 0.50 & 0.13 & 0.17 \\
\hline \multirow[t]{3}{*}{ No. of companies } & \multicolumn{4}{|c|}{14} & \multicolumn{4}{|c|}{49} \\
\hline & \multicolumn{8}{|c|}{ Year in which the bankruptcy ended } \\
\hline & \multicolumn{4}{|c|}{ Change in ownership } & \multicolumn{4}{|c|}{ No change in ownership } \\
\hline Equity holdings & Min. & Max. & Mean & $\begin{array}{c}\text { Std. } \\
\text { deviation }\end{array}$ & Min. & Max. & Mean & $\begin{array}{c}\text { Std. } \\
\text { deviation }\end{array}$ \\
\hline Individuals & 0.00 & 1.00 & 0.13 & 0.27 & 0.00 & 1.00 & 0.54 & 0.44 \\
\hline Corporations & 0.00 & 1.00 & 0.63 & 0.43 & 0.00 & 1.00 & 0.44 & 0.44 \\
\hline State & 0.00 & 1.00 & 0.22 & 0.37 & 0.00 & 0.34 & 0.01 & 0.05 \\
\hline Banks & 0.00 & 0.21 & 0.03 & 0.06 & 0.00 & 0.26 & 0.01 & 0.04 \\
\hline $1^{\text {st }}$ largest owner & 0.12 & 1.00 & 0.67 & 0.31 & 0.17 & 1.00 & 0.74 & 0.28 \\
\hline $2^{\text {nd }}$ largest owner & 0.00 & 0.33 & 0.11 & 0.11 & 0.00 & 0.50 & 0.13 & 0.16 \\
\hline No. of companies & \multicolumn{4}{|c|}{14} & \multicolumn{4}{|c|}{49} \\
\hline
\end{tabular}

still in progress during the time the research was conducted. In the companies in which the owners retained a decreased equity share after the adoption of a reorganisation plan, the average decrease in the ownership share was $57 \%$. It could be observed that the ownership structure changed as a result of the following occurrences: debt-to-equity conversions (11 cases), new investments made by a strategic partner ( 1 case), and termination of privatisation contracts, whereby the state became a major proprietor of the reorganised company ( 2 cases). In all cases in which the ownership structure changed as a result of debt-equity swaps, commercial creditors became the major owners of the reorganised companies, while in only 3 companies did the banks have an equity share after the adoption of the reorganisation plan. The average time needed to resolve the bankruptcy case was longer for companies with a changed ownership structure: 17.3 months compared with 10.1 months for companies with an unchanged ownership structure.

Of the 49 companies in which the ownership structure remained unchanged, the companies' managerial functions in 35 continued to include the involvement of the existing owners or their family members after the adoption of the reorganisation plan, in comparison to the filing year, where this was observed in 37 
companies. In some cases, however, the owners' rights were partially limited as a result of plans to establish a creditors' committee or another similar body. In 24 companies with an unchanged ownership structure, the reorganisation plan envisaged the establishment of such a body, which would be tasked with monitoring the company's performance during the reorganisation or providing consent to financial or investment decisions.

In order to test our hypotheses, we have introduced variables and defined appropriate models.

\subsection{Model inputs}

We used one dependent variable and four sets of explanatory variables.

\section{Dependent variable}

The dependent variable was OWN CHANGE, which observed two outcomes: we attributed 1 in the event that the ownership structure has undergone changes after the filing year or in the year after the adoption of the reorganisation plan, and 0 if no change is made to the ownership structure during the observed period. We consider that the ownership structure has undergone a change if the following has occurred:

(1) The ownership structure is completely changed (i.e. the previous owners do not retain an equity interest in the reorganised company),

(2) Owners with an equity interest of $25 \%$ or more do not retain their share in the reorganised company, or this share is less than $25 \%$ after the adoption of the reorganisation plan, or

(3) The new owner acquires not less than $25 \%$ of the equity shares in the reorganised company.

The second and the third definition of change in the ownership structure follow the concept of corporate control used herein.

The change in the ownership structure is observed during the bankruptcy proceedings and one year after the adoption of the reorganisation plan. From our point of view, these changes are closely linked to financial distress. We equally observe the following types of change in ownership structure: sales of equity holdings by existing owners, debt-equity swaps, investments by third parties made during the bankruptcy proceedings or after the reorganisation plan was adopted, which were converted into capital, and cases in which the state became the major proprietor as a result of the termination of privatisation contracts. We classified cases in which the owner dies as a non-turnover event. In the RS, hostile takeovers during 
bankruptcies rarely occur, and in most cases, the existing owners independently, or jointly with creditors, find strategic investors who are willing to acquire an equity share in the distressed company, purchase debts from existing creditors or invest resources in the distressed company, and at a later stage, convert their claims into equity. These transactions are finalised before or immediately after the adoption of the reorganisation plan. On the other hand, debt-equity swaps in the RS occur less frequently - first, because the opportunity to sell an equity share during the reorganisation period is small due to the lack of large investors that are willing to buy shares in companies that are in financial distress, while a secondary market for these shares is practically non-existent. Moreover, banks, as main creditors of the corporate sector, are constrained by the Law on Banks to perform debt-to-equity conversions and they also do not have an interest in being involved in the equity of distressed companies. The existing Law on Banks limits a bank's investments in the equity of a single company to $10 \%$ of the bank's capital. This limitation applies to all banks, and there is no exception in the case of debt-equity swaps in bankruptcy proceedings.

In order to identify the factors that influence change in the ownership structure, we employed 4 sets of explanatory variables.

\section{Explanatory variables}

\section{- The first set}

Size. Change in corporate control is less likely to occur in large companies, as found in Köke (2001) and Heiss - Köke (2004). This can be explained by the fact that monitoring and agency costs could be greater in larger firms. To avoid these costs, creditors may have fewer incentives to convert their claims into equity, and potential buyers may be less interested in acquiring shares in larger companies that are in financial distress. The logarithm of a company's total assets and sales $(\log (\mathrm{AT}), \log (\mathrm{S}))$ is used to measure the size.

Complexity of ownership structure. Companies with a more complex ownership structure are less likely to experience a change in ownership (Köke 2001; Heiss - Köke 2004). This can be attributed to the fact that they may have higher costs of monitoring, which imposes a need for employing more skilled managers and the greater involvement of owners in the monitoring. In order to avoid such costs, creditors may have fewer incentives to convert their claims into equity, while potential buyers may be less motivated to acquire shares in companies with a more complex ownership structure. Based on our data sample, we have only analysed a pyramid structure, while cross-ownership was not analysed, bearing in mind that it was infrequent. In this respect, we introduced a dummy variable PYRAMID in 
our model, whose presence designates a value of 1 or whose absence designates a value of 0 . We analyse the influence of the company's size and the complexity of the ownership structure together because we assumed that larger companies will be more likely to have a complex ownership structure.

\section{- The second set}

Ownership concentration. Ownership concentration acts as an important mechanism of corporate governance. The business of distressed companies is highly dependent on the existing owners, because they are in the unique position of being well conversant with the company's business, and their reputation and political connections give them power over the bankruptcy proceedings. Furthermore, large equity holders may prefer to sell whole equity holdings rather than just a portion, thereby making the process of finding potential buyers more difficult, particularly for companies in financial distress.

In order to measure ownership concentration, the average size of the largest equity holder must be included. The variable $\log (\mathrm{M} 1)$ is introduced in the research, which represents the logarithm of one plus the equity holdings of the first largest proprietor. Due to the presence of instances of high ownership concentration within our sample, the equity holdings of the second and third largest owners as explanatory variables were excluded from our models. With regard to companies with complex ownership structures, in order to identify whether a company has a high ownership concentration, it is necessary to identify the presence of an ultimate owner. This research uses the concept of corporate control developed by Heiss - Köke (2004, p. 192), who advocate the application of the three following rules:

Rule 1 (Strong Ownership Rule): A chain of control is pursued to the following level, if $50 \%$ or more of the analysed shareholder is owned by a shareholder at the next level, while all other shareholders at the next level possess less than 50\%.

Rule 2 (Weak Ownership Rule): If the strong ownership rule cannot be applied, a chain of control is pursued to the following level if $25 \%$ or more of the analysed shareholder is owned by a shareholder at the next level, while all other shareholders at the next level possess less than $25 \%$.

Rule 3 (Stop Rule): If Rules 1 and 2 cannot be applied, a chain of control is not pursued further, signifying that the company does not have an ultimate owner. We have applied the same rule in the case of reorganised companies in which the state is in possession of the major ownership share.

At a given level of the ownership concentration, the thresholds of $50 \%$ and $25 \%$ provide to an ultimate shareholder sufficient voting rights to exercise significant influence over a company's decision-making process. 
In counting ultimate voting rights, the "weakest link" principle was employed. If a shareholder controls a share of $x$ of the votes within company A, which equally controls a share of $y$ of the votes within another company (company B), it is assumed that this shareholder controls the share of either $x$ or $y$, depending on which of these two values is lower. For a large number of the companies, information regarding voting rights was not publicly available; therefore, instead of voting rights, we used cash flow rights in determining the presence of an ultimate owner. This approach did not distort the results obtained, given the fact that the majority of Serbian companies respect the one share, one vote rule.

In order to determine the influence of ownership concentration on the probability of a change in ownership structure, in addition to the $\log (\mathrm{M} 1)$ variable, the dummy variable CONTROL has been employed in our research, whereby it is presented as a value of 1 in the presence of an ultimate owner (based on Rules 1 or 2 as outlined above), or as a value of 0 if the ownership structure is determined to be dispersed (based on Rule 3 as outlined above). Despite the fact that previous research used the Herfindahl Index as a measure of ownership concentration, we were not able to use this indicator in our research due to the fact that it is not publicly available for the companies in our sample, and cannot be calculated based on the publicly available data.

Dual function of the owners. Poor performance may be the result of weak management and, consequently, companies in financial distress that have weak management are more likely to be the subject of acquisitions and/or debt-to-equity conversions (empirically confirmed for the US market). In the case of the RS, in the event that creditors and potential buyers determine a company's management as being the main cause of its financial distress, the probability of a change in ownership structure could be higher if the owners and their family members were involved in management functions in the past (intuitive assumption). In order to account for the influence of dual functions carried out by the owners, the dummy variable MANAGEMENT was introduced, given a value of 1 if the ultimate owner or a member of his/her family is also a member of the Board of Directors, a member of the Supervisory Board, or a Director, while a value of 0 is attributed to this variable if these actors have not held the aforementioned positions before or during the filing year, or during bankruptcy. For the purpose of this research, family members are defined as individuals with the same last name as the owner.

\section{- The third set}

Financial performance. Reorganisation plans are more likely to permit the old owners to keep their equity holdings in the reorganised company when the company is solvent at the confirmation of the plan (LoPucki - Whitford 1993). In 
order to isolate the influence of the decisions made during the bankruptcy period, we have used financial figures that stem from the end of the fiscal year prior to bankruptcy. The same approach was used by LoPucki - Whitford (1993). In order to measure the degree of a company's indebtedness, we used the current ratio (LIQUIDITY), calculated as a ratio between current assets and current liabilities, and the debt/equity ratio (LEVERAGE), which compares the book value of total debt to the book value of total debt and equity combined. As a measure of the company's profitability, we used ROA, EBITDA margin and the company's unanticipated earnings ( $\triangle$ EBIT/AT). ROA is calculated by dividing a company's annual earnings by average assets. The EBITDA margin (EBITDAMARGIN) is calculated as a ratio of EBITDA to sales revenue, whereby EBITDA is defined as the earnings before interest, taxes, depreciation, and amortisation. The company's unanticipated earnings ( $\triangle$ EBIT/AT) are calculated as the annual difference in earnings before interest and taxes (EBIT), divided by the book value of assets at the beginning of the year (T-2), an indicator also used by Gilson (1990) in similar research.

\section{- The fourth set}

Bankruptcy duration. The effect of the time spent in bankruptcy on changes in ownership structure could be explained in two ways. First, as time passes, the bargaining power of the existing owners may decrease due to the decrease in the company's overall value, which, in turn, reduces the readiness of creditors to keep the existing owners and management within the company. Second, in almost all cases, an insolvency administrator is in charge of a company's affairs, which decreases the dependency of the company's business on the existing owners and increases the probability that the existing owners will be replaced by creditors or potential investors. In order to include the influence of the time spent in bankruptcy on the dependent variable, our research introduced the explanatory variable BANKRUPTCY TIME (log of one plus the number of months between the bankruptcy filing date and the date the bankruptcy ended). Furthermore, in order to take into account the entire period a company has spent in bankruptcy, the bankruptcy filing year represents the date when the court reached the decision to open bankruptcy, while the year in which the bankruptcy ended is determined by the date that the court's decision confirming the adoption of the reorganisation plan is final.

See Appendix 2 for a summarised list of the variables used in this research. 


\subsection{Models}

In order to test the relationship between financial distress and ownership turnover, we used the following general specifications:

(1) Ownership turnover $=\mathrm{f}$ ( size variables, complexity of ownership structure variables), and the relevant model can be written as follows:

OWN CHANGE $=\beta 1 \times \log ($ AT $)+\beta 2 \times \log (\mathrm{S})+\beta 3 \times$ PYRAMID $+\varepsilon$

(2) Ownership turnover $=f$ (ownership concentration variables, dual function variable), and the model is:

OWN CHANGE $=\beta 1 \times \log (\mathrm{M} 1)+\beta 2 \times$ CONTROL $+\beta 3 \times$ MANAGEMENT $+\varepsilon$

(3) Ownership turnover $=f$ (financial performance variables, leverage variables), and the accompanying model is:

OWN CHANGE $=\beta 1 \times$ LEVERAGE $+\beta 2 \times$ LIQUIDITY $+\beta 3 \times$ ROA $+\beta 4$ $\times$ EBITDAMARGIN $+\beta 5 \times \Delta$ EBIT $/$ AT $+\varepsilon$

(4) Ownership turnover $=f$ (bankruptcy duration variable), and the model is:

OWN CHANGE $=\beta 1 \times$ BANKRUPTCY TIME $+\varepsilon$

where $\varepsilon$ represents random error.

In order to test the influence of the observed explanatory variables on the dependent variable, we used binary logistic regression (BLR), which is one of the most prominent models employed in economic research regarding change in corporate control (Abatecola et al. 2011). The independent variables were included in our models by applying the enter method, whereby all variables are included in the model simultaneously, and all regressions were run using SPSS software.

\section{RESULTS}

Table 4 shows the ability of all of the tested models to predict change in ownership structure in distressed companies. The overall percentage demonstrates that all four models have a similar predictive power (app. 80\%). However, based on the Nagelkerke R Square and the Hosmer-Lemeshow Test significance, we can reach the conclusion that the second and third model has a better predictive power than the first and fourth model.

Table 5 shows the BLR estimates for the four models, in which the explanatory variables were included in the model simultaneously.

The significance of the explanatory variables presented in Table 5 demonstrates that the company's size, the complexity of its ownership structure, its ownership concentration, its financial performance, and its leverage variables are not significant determinants of ownership turnover. Instead, the involvement of the owners 
Table 4. Predictive power of the models

\begin{tabular}{|c|c|c|c|c|c|c|c|c|c|c|c|c|c|}
\hline \multirow{2}{*}{\multicolumn{2}{|c|}{ Observed }} & \multicolumn{3}{|c|}{ First model } & \multicolumn{3}{|c|}{ Second model } & \multicolumn{3}{|c|}{ Third model } & \multicolumn{3}{|c|}{ Fourth model } \\
\hline & & \multicolumn{2}{|c|}{$\begin{array}{c}\text { OWN. } \\
\text { CHANGE }\end{array}$} & \multirow{2}{*}{ 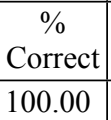 } & \multicolumn{2}{|c|}{$\begin{array}{c}\text { OWN. } \\
\text { CHANGE }\end{array}$} & \multirow{2}{*}{ 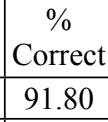 } & \multicolumn{2}{|c|}{$\begin{array}{c}\text { OWN. } \\
\text { CHANGE }\end{array}$} & \multirow{2}{*}{\begin{tabular}{|c|c}
$\begin{array}{c}\% \\
\text { Correct }\end{array}$ \\
95.90 \\
\end{tabular}} & \multicolumn{2}{|c|}{$\begin{array}{c}\text { OWN. } \\
\text { CHANGE }\end{array}$} & \multirow{2}{*}{ 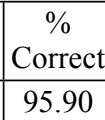 } \\
\hline OWN. & 0 & 49 & 0 & & 45 & 4 & & 47 & 2 & & 47 & 2 & \\
\hline CHANGE & 1 & 13 & 1 & 7.10 & 9 & 5 & 35.70 & 10 & 4 & 28.60 & 11 & 3 & 21.40 \\
\hline $\begin{array}{l}\text { Overall } \\
\text { percentage }\end{array}$ & & & & 79.40 & & & 79.40 & & & 81 & & & 79.40 \\
\hline $\begin{array}{l}\text { Nagelkerke } \\
\text { R Square }\end{array}$ & & \multicolumn{3}{|c|}{0.08} & \multicolumn{3}{|c|}{0.29} & \multicolumn{3}{|c|}{0.13} & \multicolumn{3}{|c|}{0.16} \\
\hline $\begin{array}{l}\text { Hosmer- } \\
\text { Lemeshow } \\
\text { Test sig. }\end{array}$ & & \multicolumn{3}{|c|}{0.91} & \multicolumn{3}{|c|}{0.81} & \multicolumn{3}{|c|}{0.56} & \multicolumn{3}{|c|}{0.24} \\
\hline
\end{tabular}

in the management of distressed companies and the time needed to resolve a bankruptcy case become the key factors in the determination of the probability of ownership change. In companies in which the owners were involved in the management before they file for bankruptcy, ownership turnover is more likely to occur. Also, changes in ownership structure are more likely to occur in companies that spend more time in resolving a bankruptcy case. The sign of the coefficient of all explanatory variables, except for Log(AT), LEVERAGE, and ROA, is consistent with the assumptions made in the research. Finally, Table 5 reports that Hypotheses 1 and 3 do not moderate the relationship between financial distress and ownership turnover, Hypothesis 2 partially moderates, while Hypothesis 4 strongly moderates.

\section{Limitations}

This research encountered three significant limitations. Firstly, despite the fact that large and medium-sized companies in Serbia are subject to external financial audits, financial reports continue to contain hidden losses. For this reason, the ratios calculated in this research may not be fully reliable or accurate. Secondly, due to the relatively small number of observations within the category of changed ownership structure, variables with non-significant effects might be estimated to be smaller than those with significant effects. To be able to detect reasonable size effects with reasonable power, future research will need to have at least $10 \mathrm{ob-}$ servations per estimated variable (Peduzzi et al. 1996). Thirdly, Durbin-Watson statistics indicate the presence of positive autocorrelation in our models, while the graphical representation of the residuals indicates the absence of autocorrelation. The source of the potential autocorrelation could be a misspecification of the 
Table 5. Predictive power of the models

\begin{tabular}{l|l|c|c|c|c|c|c}
\hline \multicolumn{9}{c}{} & First model \\
\hline & & B & S.E. & Wald & df & Sig. & Exp(B) \\
\hline Step 1 & Log(AT) & 0.88 & 1.06 & 0.69 & 1 & 0.41 & 2.41 \\
\hline & Log(S) & -0.93 & 0.60 & 2.38 & 1 & 0.12 & 0.39 \\
\cline { 2 - 8 } & PYRAMID & -0.62 & 0.67 & 0.86 & 1 & 0.35 & 0.54 \\
\cline { 2 - 8 } & Constant & -1.30 & 3.43 & 0.14 & 1 & 0.71 & 0.27 \\
\hline
\end{tabular}

a. Variable(s) entered in step 1: LogAT, LogS, PYRAMID

Second model

Variables in the equation

\begin{tabular}{|c|c|c|c|c|c|c|c|}
\hline & $\mathrm{B}$ & S.E. & Wald & $\mathrm{df}$ & Sig. & $\operatorname{Exp}(B)$ \\
\hline \multirow[t]{4}{*}{ Step $1^{\mathrm{a}}$} & $\log (\mathrm{M} 1)$ & -8.37 & 6.43 & 1.70 & 1 & 0.19 & 0.00 \\
\hline & CONTROL & -1.07 & 1.05 & 1.04 & 1 & 0.31 & 0.34 \\
\hline & MANAGEMENT & 2.22 & 0.74 & 9.10 & 1 & 0.00 & 9.25 \\
\hline & Constant & -0.28 & 1.70 & 0.03 & 1 & 0.87 & 0.75 \\
\hline
\end{tabular}

a. Variable(s) entered in step 1: LogM1, CONTROL, MANAGEMENT

Third model

\begin{tabular}{|c|c|c|c|c|c|c|c|}
\hline \multicolumn{8}{|c|}{ Variables in the equation } \\
\hline & & $\mathrm{B}$ & S.E. & Wald & $\mathrm{df}$ & Sig. & $\operatorname{Exp}(\mathrm{B})$ \\
\hline \multirow[t]{6}{*}{ Step $1^{\mathrm{a}}$} & LIQUIDITY & -1.08 & 1.11 & 0.94 & 1 & 0.33 & 0.34 \\
\hline & LEVERAGE & -0.74 & 1.01 & 0.53 & 1 & 0.47 & 0.48 \\
\hline & ROA & 7.97 & 6.24 & 1.63 & 1 & 0.20 & $2,898.24$ \\
\hline & EBITDAMARGIN & -0.14 & 0.15 & 0.94 & 1 & 0.33 & 0.87 \\
\hline & $\Delta \mathrm{EBIT} / \mathrm{AT}$ & -8.21 & 5.78 & 2.01 & 1 & 0.16 & 0.00 \\
\hline & Constant & 0.19 & 1.02 & 0.03 & 1 & 0.86 & 1.20 \\
\hline \multicolumn{8}{|c|}{ a. Variable(s) entered in step 1: LIQUIDITY, LEVERAGE, ROA, EBITDAMARGIN, EBITAT } \\
\hline \multicolumn{8}{|c|}{$\begin{array}{ll} & \text { Fourth model } \\
\end{array}$} \\
\hline \multicolumn{8}{|c|}{ Variables in the equation } \\
\hline & & $\mathrm{B}$ & S.E. & Wald & df & Sig. & $\operatorname{Exp}(\mathrm{B})$ \\
\hline \multirow[t]{2}{*}{ Step $1^{\mathrm{a}}$} & $\begin{array}{l}\text { BANKRUPTCY } \\
\text { TIME }\end{array}$ & 3.06 & 1.25 & 6.01 & 1 & 0.01 & 21.26 \\
\hline & Constant & -4.54 & 1.44 & 9.92 & 1 & 0.00 & 0.01 \\
\hline \multicolumn{5}{|c|}{ a. Variable(s) entered in step 1: BANKRUPTCY TIME } & & & \\
\hline
\end{tabular}

functional form of the models. However, the limited number of observations and the lack of similar research for transition economies do not allow us to define the models more broadly.

Despite the aforementioned limitations, the results offer valuable insights regarding the existing corporate governance practice in distressed companies in Serbia. 


\section{DISCUSSION}

Our research demonstrated that financial distress has no significant effect on ownership structure in the vast majority of companies. The BLR estimates show that the previous involvement of the owners in the company's management and the time spent in bankruptcy increase the probability of ownership turnover, while the influence of all other variables on the ownership structure was deemed to be statistically insignificant. We also observed that the present owner and their family members retain the key management positions in the reorganised companies. These findings differ considerably from those that have been reported in the case of the US and Germany, and several factors can be used to elaborate on the results obtained. Firstly, the business of the reorganised companies is highly dependent on the existing owners. They are in the unique position of knowing the company's business and the reasons for its financial distress, while their reputation and political connections give them sufficient power over the bankruptcy proceedings. In such situations, the market for corporate control will function poorly, as the company's insiders cannot be challenged. Secondly, great uncertainty and asymmetric information between the company's management and the claimants place creditors at a serious disadvantage in comparison to the company's managers and owners. Furthermore, some of the creditors have state ownership and have less incentive to be strong debt collectors. Altogether, this results in a passive role of creditors in the bankruptcy process. Thirdly, due to the undeveloped capital market and poor legal protection for minority shareholders, any dilution of ownership would lead to poor financial performance in distressed companies, and creditors might avoid debt-equity swaps. Lastly, as Gray et al. (1996) also point out, control rights will not necessarily change when the whole economy is facing crises because the financial distress may not be caused by internal deficiencies in the mechanisms of corporate control.

The current practice in the RS could be changed by strengthening banking and bankruptcy regulation reforms, improving macroeconomic discipline, and imposing liability on a company's management to provide the requisite transparency to all of the company's investors. Moreover, an active role of banks in bankruptcy proceedings and the acceleration of corporate governance changes can help the banking sector to resolve the problem of growing NPL portfolios, and enable the rehabilitation of the Serbian corporate sector, which is facing a lack of liquidity and solvency.

This study produced conceptual and methodological implications for future research and the practice of corporate governance in distressed companies in transition economies. At this moment, the number of observations is too limited to allow generalisations; however, future studies should define a model that tests 
the influence of financial distress on the mechanisms of corporate control more broadly. Also, we recommend future research to examine whether changes in ownership structure affect the long-term performance of reorganised companies and, consequently, their chances for survival. Two important research questions that should be addressed are whether the disposal of the equity of existing owners and their replacement in key managerial positions by new managers with skills in managing distressed companies have the potential to facilitate reforms pertaining to corporate governance in transition economies; and furthermore, whether the existence of multiple large-scale shareholders and vulture investors might facilitate investments in financially distressed companies. In the event of a positive answer to both of these queries, it could be expected that changes in the corporate governance of distressed companies would foster the development of primary and secondary markets for these companies.

\section{REFERENCES}

Abatecola, G. - Farina, V. - Gordini, N. (2011): Empirical Research on Corporate Distress: Assessing the Role of the Boards of Directors. Presentation at XX Tor Vergata Conference on "Money, Banking and Finance: Actors, Rules and Policies after the Global Financial Crisis", Tor Vergata University, Rome, December 5-7, 2011.

Asquith, P. - Gertner, R. - Scharfstein, D. (1994): Anatomy of Financial Distress: An Examination of Junk-Bond Issuers. The Quarterly Journal of Economics, 109(3): 625-658.

Balcerowicz, E. - Hashi, I. - Lowitzsch, J. - Szanyi, M. (2003): The Development of Insolvency Procedures in Transition Economies: A Comparative Analysis. Paisley Business School Working Paper Series, No. 2003/2.

Betker, B. L. (1995): An Empirical Examination of Pre-Packaged Bankruptcy. Financial Management, 24(1): 3-18.

Cerovic, S. - Stanisic, N. - Radojevic, T - Radovic, N. (2014): The Impact of Ownership Structure on Corporate Performance in Transitional Economies. Amfiteatru Economic, 17(38): 441-454.

Franks, J. - Mayer, C. (2000): Ownership and Control of German Corporations. Review of Financial Studies, 14(4): 943-977.

Gilson, S. C. (1989): Management Turnover and Financial Distress. Journal of Financial Economics, 25(2): 241-262.

Gilson, S. C. (1990): Bankruptcy, Boards, Banks, and Blockholders. Journal of Financial Economics, 27(2): 355-387.

Gilson, S. C. - Hotchkiss, E. S. - Ruback, R. S. (2000): Valuation of Bankrupt Firms. Review of Financial Studies, 13(1): 43-74.

Gray, W. C. - Schlorke, S. - Szanyi, M. (1996): Hungary's Bankruptcy Experience, 1992-93. The World Bank Economic Review, 10(3): 425-450.

Heiss, F. - Köke, J. (2004): Dynamics in Ownership and Firm Survival: Evidence from Corporate Germany. European Financial Management, 10(1): 167-195.

Jory, S. - Madura, J. (2010): The Long-Run Performance of Firms Emerging from Chapter 11 Bankruptcy. Applied Financial Economics, 20(14): 1145-1161. 
Jostarndt, P. - Sautner, Z. (2006): Financial Distress, Corporate Control, and Management Turnover. Journal of Banking and Finance, 32(10): 2188-2204.

Köke, J. (2000): Control Transfers in Corporate Germany: Their Frequency, Causes, and Consequences. ZEW Discussion Paper, No. 00-67. Centre for European Economic Research Mannheim.

LoPucki, L. M. - Whitford, W. C. (1993): Patterns in the Bankruptcy Reorganization of Large Publicly Held Companies. Carnell Law Review, 78(4): 597-618.

Peduzzi, P. - Concato, J. - Kemper, E. - Holford, T. R. - Feinstein, A. R. (1996): A Simulation Study of the Number of Events per Variable in Logistic Regression Analysis. Journal of Clinical Epidemiology, 49(2): 1373-1379.

Schaffer, M. (1998): Do Firms in Transition Economies Have Soft Budget Constraints? A Reconsideration of Concepts and Evidence. Journal of Comparative Economics, 26(1): 80-103.

Szanyi, M. (2016): The Reversal of the Privatisation Logic in Central European Transition Economies. Acta Oeconomica, 66(1): 33-55.

Wang, C. (2012): Determinants of the Choice of Formal Bankruptcy Procedure: An International Comparison of Reorganization and Liquidation. Emerging Markets Finance and Trade, 48(2): 4-28.

World Bank (2015): http://knoema.com/WBDB2014/world-bank-doing-business-2015http://knoema.com/WBDB2014/world-bank-doing-business-2015 


\section{APPENDIX 1}

Comparison of the US, German and Serbian bankruptcy rules

\begin{tabular}{|c|c|c|c|}
\hline Characteristics & United States & Germany & Republic of Serbia \\
\hline $\begin{array}{l}\text { Right to initiate the } \\
\text { process }\end{array}$ & $\begin{array}{l}\text { Debtor within } 180 \\
\text { days. After the } \\
\text { exclusivity period } \\
\text { expires, the plan can } \\
\text { file other parties in } \\
\text { interest in a case. }\end{array}$ & Debtor and creditors. & $\begin{array}{l}\text { Debtor can file Pre- } \\
\text { pack Reorganisation } \\
\text { Plan, while debtor, } \\
\text { creditor, owner, } \\
\text { or insolvency } \\
\text { administrator can } \\
\text { file a reorganisation } \\
\text { plan in a regular } \\
\text { bankruptcy procedure. }\end{array}$ \\
\hline $\begin{array}{l}\text { Private benefits } \\
\text { for the company's } \\
\text { stakeholders }\end{array}$ & $\begin{array}{l}\text { Gives considerable } \\
\text { weight to the private } \\
\text { benefits of distressed } \\
\text { firm's stakeholders. }\end{array}$ & $\begin{array}{l}\text { May play an } \\
\text { important role in the } \\
\text { restructuring of the } \\
\text { distressed firm. }\end{array}$ & $\begin{array}{l}\text { Do not play an } \\
\text { important role in the } \\
\text { restructuring of the } \\
\text { distressed firm. }\end{array}$ \\
\hline $\begin{array}{l}\text { Automatic stay } \\
\text { provision }\end{array}$ & $\begin{array}{l}\text { Most creditor claims } \\
\text { are stayed (except, } \\
\text { e.g., lease payments). }\end{array}$ & $\begin{array}{l}\text { Automatic stay for } \\
\text { unsecured; minimum } \\
\text { of three months for } \\
\text { secured. }\end{array}$ & $\begin{array}{l}\text { In the case of a regular } \\
\text { bankruptcy procedure, } \\
\text { AS rule is applied } \\
\text { to all creditors, } \\
\text { while in the case } \\
\text { of a pre-insolvency } \\
\text { restructuring } \\
\text { proceeding, it applies, } \\
\text { on the request of a } \\
\text { judge, to all or some } \\
\text { creditors. }\end{array}$ \\
\hline $\begin{array}{l}\text { Control rights during } \\
\text { bankruptcy }\end{array}$ & Debtor in control. & $\begin{array}{l}\text { Creditor's committee } \\
\text { in control. }\end{array}$ & $\begin{array}{l}\text { In almost all } \\
\text { cases, the court } \\
\text { appoints insolvency } \\
\text { administrators who } \\
\text { control the company's } \\
\text { business. }\end{array}$ \\
\hline $\begin{array}{l}\text { Preservation of } \\
\text { residual claims of } \\
\text { equity holders }\end{array}$ & $\begin{array}{l}\text { In majority of cases, } \\
\text { deviations from } \\
\text { absolute priority in } \\
\text { favour of equity. }\end{array}$ & $\begin{array}{l}\text { Deviations can be } \\
\text { proposed, but must be } \\
\text { approved (i.e. voted } \\
\text { on) by creditors. }\end{array}$ & $\begin{array}{l}\text { The owners do not } \\
\text { vote on the plan and } \\
\text { deviations from AP } \\
\text { rule must be approved } \\
\text { (i.e. voted on) by } \\
\text { creditors. }\end{array}$ \\
\hline Approval condition & $\begin{array}{l}\text { The plan is accepted } \\
\text { by creditors that hold } \\
\text { at least two-thirds in } \\
\text { amount and more than } \\
\text { one-half of the number } \\
\text { of the allowed claims } \\
\text { in the class. }\end{array}$ & $\begin{array}{l}\text { The plan is accepted } \\
\text { by a simple majority } \\
\text { of each class and } 1 / 2 \\
\text { volume of claims } \\
\text { with prohibition on } \\
\text { obstruction. }\end{array}$ & $\begin{array}{l}\text { The plan is accepted } \\
\text { by a simple majority } \\
\text { of each class and } 1 \frac{2}{2} \\
\text { volume of claims, } \\
\text { creditor's obstruction } \\
\text { is not restricted. }\end{array}$ \\
\hline
\end{tabular}

Source: The rules for the US and Germany have been summarised by Wang (2012: 5) and Balcerowicz et al. (2003: 15), while the rules applicable for Serbia have been summarised by the authors. 


\section{APPENDIX 2}

Overview of the research variables

\begin{tabular}{|c|c|}
\hline Variable names & Definition \\
\hline OWN CHANGE & $\begin{array}{l}\text { A dummy variable with a value of } 1 \text { if ownership changes, } \\
\text { otherwise, a value of } 0\end{array}$ \\
\hline $\log (\mathrm{AT})$ & $\begin{array}{l}\text { The log of the book value of non-deflated assets, used to measure } \\
\text { the size of a company }\end{array}$ \\
\hline $\log (\mathrm{S})$ & $\begin{array}{l}\text { The log of the book value of sales revenue, used to measure the } \\
\text { size of a company }\end{array}$ \\
\hline PYRAMID & $\begin{array}{l}\text { A dummy variable with a value of } 1 \text { if a company has a pyramid } \\
\text { structure, otherwise, a value of } 0\end{array}$ \\
\hline $\log (\mathrm{M} 1)$ & $\begin{array}{l}\text { The log of one plus the equity holdings of the first largest } \\
\text { proprietor }\end{array}$ \\
\hline CONTROL & $\begin{array}{l}\text { A dummy variable with a value of } 1 \text { if a company has an ultimate } \\
\text { shareholder, calculated based on the concept of control, otherwise, } \\
\text { a value of } 0\end{array}$ \\
\hline MANAGEMENT & $\begin{array}{l}\text { A dummy variable with a value of } 1 \text { if the owner or member of } \\
\text { his/her family is also a member of the Board of Directors, the } \\
\text { Supervisory Board or a Director; a value of } 0 \text { if they do not hold } \\
\text { the mentioned positions after the company reorganisation }\end{array}$ \\
\hline LIQUIDITY & The ratio of current assets to current liabilities \\
\hline LEVERAGE & $\begin{array}{l}\text { Book value of total debt to the book value of total debt and equity } \\
\text { combined }\end{array}$ \\
\hline ROA & Net income divided by average total assets \\
\hline EBITDAMARGIN & $\begin{array}{l}\text { The ratio of EBITDA (earnings before interest, taxes, depreciation, } \\
\text { and amortisation) to sales revenue }\end{array}$ \\
\hline$\Delta \mathrm{EBIT} / \mathrm{AT}$ & $\begin{array}{l}\text { Earnings before interest and taxes divided by the book value of } \\
\text { assets at the beginning of the year }\end{array}$ \\
\hline BANKRUPTCY TIME & $\begin{array}{l}\text { Log of value one plus the number of months spent from the } \\
\text { bankruptcy filing date to the date when the bankruptcy ended }\end{array}$ \\
\hline
\end{tabular}

